\title{
METODE PENGUMPULAN DATA PENELITIAN MUSIK BERBASIS OBSERVASI AUDITIF
}

\author{
Ichsan ${ }^{1}$, Arhamudin Ali \\ ${ }^{1,2}$ Prodi Seni Musik, Politeknik SOCA, Jalan Pulo Lentut No. 3 Kec. Cakung, Jakarta Timur, DKI Jakarta, Indonesia \\ ${ }^{(*)} \bowtie$ (e-mail) ichsan@soca.ac.id ${ }^{1}$, arhamuddinali@soca.ac.id²
}

\begin{abstract}
Abstrak
Tujuan penelitian ini adalah mendeskripsikan potensi pengetahuan auditif sebagai teknik observasi dalam suatu penelitian musik. Penelitian ini menggunakan metode kajian pustaka dengan pendekatan kajian musikologi. Hasil dalam penelitian ini menunjukkan bahwa teknik observasi auditif merupakan sebuah tawaran teknik observasi pada suatu penelitian yang dapat digunakan bukan hanya pada domain penelitian musik, akan tetapi dapat juga digunakan pada jenis penelitian lainnya yang bersifat antropologis dan fenomenologis. Teknik observasi merupakan teknik yang sangat lazim digunakan dalam penelitian kualitatif. Penelitian berbasis teknik observasi dalam suatu penelitian telah lama didominasi oleh observasi secara visual dibandingkan secara auditif yang sampai saat ini jarang sekali digunakan.
\end{abstract}

Kata kunci: metode penelitian, observasi, auditif, teknik enharmonik, penelitian musikal.

\begin{abstract}
The purpose of this study was to describe the potential of auditive knowledge as an observation technique in music research. This study uses a literature review method with a musicological study approach. The results in this study indicate that auditive observation technique is an offering of observation techniques in a study that can be used not only in the domain of music research, but can also be used in other types of research that are anthropological and phenomenological. The observation technique is a technique that is very commonly used in qualitative research. Observationbased research in a study has long been dominated by visual rather than auditive observation, which until now has rarely been used
\end{abstract}

Keywords: research methods, observation, auditive, enharmonics techniques, musical research.

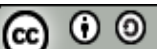

This work is licensed under a Creative Commons Attribution-ShareAlike 4.0 International License.

Copyright (C) 2020 Ichsan

Proses Artikel

Diterima 25-10-2020; Revisi 03-12-2020; Terbit Online 08-12-2020 


\section{Pendahuluan}

Teknik observasi merupakan teknik yang sangat lazim dipakai dalam penelitian kualitatif, penelitian berbasis teknik observasi dalam kancah penelitian dunia telah lama didominasi oleh observasi dengan mengandalkan indra penglihatan (visual) sebagai alat superior dibanding indra pendengaran (auditif) yang sampai saat ini masih inferior dan minim dilakukan. Hal ini dapat kita temukan pada catatan lapangan sangat bergantung dengan apa yang kita lihat secara visual, baik oleh mata peneliti maupun mata kamera sebagai alat bantu dalam mengobservasi.

Kajian tentang observasi dalam penelitian seni beberapa sudah dilakukan, namun hanya melihatnya dari perspektif visual dengan fokus kajian suasana dalam ruang penelitian (Hanik et al., 2018; Hasanah, 2017; Rahardjo, 2011). Sedangkan kajian dengan fokus auditory sebagai sebuah alternatif baik dalam proses penelitian maupun pembelajaran memberikan sebuah pemahaman tersendiri dalam penelitian ini (Eurich et al., 2019; Koelsch et al., 2019; Makhin et al., 2015; Phillips-Silver \& Trainor, 2007; Sato, 2008; Shea et al., 2001; Young et al., 2014). Penelitian ini secara khusus akan melihat posisi peneliti yang memiliki kemampuan musikal tinggi dalam melakukan pengumpulan data.

Tullisan ini merupakan tawaran dalam rangka memikirkan ulang metode observasi dengan menggunakan indra pendengaran sebagai alat pengumpulan data lapangan dalam penelitian kualitatif. Dalam beberapa penelitian mengatakan bahwa auditory merupakan salah satu indra yang sangat berpengaruh dalam kehidupan sehari-hari (Andaryani, 2019; Septiyan, 2019). Hal ini kemudian dikhususkan bagi peneliti yang memiliki pengalaman dan pemahaman musikal, salah satu alasan utama kekhususan ini dikarenakan objek yang menjadi kasus dalam esai ini berkutat pada persoalan musik dan persepsi indrawi. Tulisan ini sedikit banyak juga terinspirasi dari fenomena pengetahuan auditif tuna netra dalam kehidupan sehari-hari, juga pada keterampilan analisis pemeriksaan dokter yang mengandalkan pengetahuan dan pengalaman auditif dengan teknik auskultasi (keterampilan pemeriksaan kesehatan yang dilakukan oleh dokter dengan interpretasi auditif dengan menggunakan stetoskop sebagai alat bantu dalam mendengarkan suara yang dipancarkan oleh tubuh manusia)

Berdasarkan latar belakang di atas, pertanyaan dalam penelitian ini adalah untuk mengkaji bagaimana metode pengumpulan data penelitian musik berbasis auditif yang dapat dilakukan dalam proses penelitian baik dalam konteks penelitian musik maupun non musik. Sehingga penelitian ini bertujuan untuk mendeskripsikan potensi pengetahuan auditif sebagai teknik observasi dalam suatu penelitian musik. Hasil dari penelitian ini diharapkan menjadi sebuah wacana diskusi bagi penelitian selanjutnya.

\section{Metode}

Tulisan ini menggunakan metode kajian pustaka dalam mengumpulkan referensi dan menetapkan posisi penelitian. Beberapa konsep dalam kajian musikologi digunakan untuk memperkuat wacana auditif dalam penelitian ini. Telaah tersebut kemudian dapat memunculkan dimensi kekosongan wacana terkait persoalan metodis hari ini - khususnya dalam metode penelitian seni. Konteks kasus dalam artikel ini berkaitan dengan pemilihan subjek penelitian berdasarkan tiga peristiwa musikal yakni observasi musik live, semi live, dan non-live dalam rangka mempertanyakan bagaimana manusia hadir dalam tiga jenis peristiwa 
tersebut?". Aktivitas mendengar dan mendengarkan menjadi titik tolak dalam penelitian ini, mengingat indra utama dalam menikmati musik pada dasarnya menggunakan indra pendengaran.

Problematisasi tersebut berangkat dari perdebatan teoretis dalam wacana estetika liveness yang sampai hari ini masih berdiri pada dua kutub. Kutub yang satu berdiri pada pemikiran bahwa manusia dikatakan hadir dalam menikmati seni ketika kehadiran tubuh, ruang, dan waktu secara simultan - pemikiran ini juga disebut sebagai wacana liveness klasik (Phelan, 1993), sedangkan kutub yang lainnya berdiri pada pemikiran bahwa untuk hadir dalam menikmati seni cukup dengan "atensi", bahkan tanpa simultanitas tubuh, ruang, dan waktu (Auslander, 2008).

\section{Hasil}

\section{Teknik Enharmonik Sebagai Observasi Auditif dalam Penelitian Musik}

Enharmonik merupakan istilah yang dipinjam dari salah satu teknik pembacaan notasi musik. The New Harvard Dictionary of Music mendefinisikan enharmonik sebagai nada yang satu dan sama walaupun diberi nama atau dieja secara berbeda (Apel, 2003, p. 288). Ketika penamaan suatu notasi dikatakan berbeda pada peristiwa nada enharmonik, meskipun pada tataran bunyi yang sama, maknanya tentu berbeda. Salah satu contoh, meskipun D\# dan Eb pada frekuensi dan pitch yang sama, secara makna, D\# merupakan nada dengan frekuensi yang meningkat dengan tanda "\#" yang berjarak setengah langkah lebih tinggi setelah nada D. Kemudian Eb merupakan nada dengan frekuensi yang lebih rendah dengan tanda " $b$ " yang berjarak setengah langkah lebih rendah dari nada $E$. begitu pula dari sudut pandang pemain. D\# dan Eb akan selalu dibaca berdasarkan huruf yang berada di depan tanda "\#" atau " $b$ ". Jika dikontektualisasikan pada kasus tulisan ini, kegiatan mendengar musik itu satu, meskipun secara peristiwa disebut berbeda, yakni live, semi-live, dan non-live.

Terdapat Interval tertentu yang dapat dihilangkan menggunakan nada enharmonik untuk mendapatkan hasil yang berbeda. Contoh yang umumnya ditemui adalah Interval Augmented Sixth dan minor seventh. Kita tidak akan mendengar perbedaan antara bentuk interval Augmented Sixth dan minor seventh, telinga kita akan mendengar Interval yang sama. Hal tersebut terkait dengan proyeksi suara, atau praktik membunyikan not dengan cara yang paling mudah dinyanyikan. Begitu pula yang terjadi dalam observasi enharmonik, semua musik yang didengarkan menggunakan kriteria musik umum-populer, dalam hal ini, pemilihan musik yang dipilih hanya pada tataran musik konvensional, tidak termasuk musik kontemporer. Hal ini dikarenakan alasan praktis untuk memudahkan pengumpulan data, juga disebabkan oleh pemilihan gendre bukanlah hal yang disoroti dalam tulisan ini, melainkan dimensi kehadiran manusia dalam mendengar.

Pada praktik musikal pengertian enharmonik mengandalkan elemen visual dengan membaca notasi yang kemudian diikuti dengan analisis praktik musikal (memainkan instrumen) dan analisis pendengaran, sehingga dapat mengidentifikasi bunyi yang sama pada pembacaan yang berbeda. Sedangkan pada pengertian teknik observasi enharmonik dalam pengumpulan data kualitatif pada musik, yang dibutuhkan adalah kepekaan mendengar dan keterampilan mendengarkan tanpa unsur visual sedikitpun. 
Sebagaimana etimologi enharmonik dalam musik yang melakukan pembacaan dan penamaan berbeda pada kasus nada yang sama, teknik enharmonik sebagai metode pengumpulan data adalah dengan melakukan pembacaan berbeda pada aktivitas yang sama, yakni mendengarkan.

Beberapa hal yang berkaitan dengan pengaplikasian teknik enharmonik dalam pembahasan di atas, akan dikaji lebih lanjut dalam pembahasan selanjutnya. Masing-masing pengumpulan data dilakukan berdasarkan kaidah dan ciri masing-masing peristiwa yang diamati. Pada peristiwa mendengarkan pertama, data peristiwa musik live dibaca sesuai dengan kaidah dan keadaan dimensi musik live, yakni pada kaidah akustik murni tanpa mediasi, baik gema-resonansi, human error, keterbatasan kontrol atas volume suara, kecepatan ritme yang bisa berubah kapan pun tanpa metronome, sampai pada desah pengaturan nafas pemain musik.

Pada peristiwa musik kedua, data peristiwa Musik semi-live kemudian dapat kita baca berdasarkan gabungan antara prinsip akustik dan akusmatik, hampir sama dengan peristiwa musik live, namun ada penambahan satu kriteria yang merupakan prinsip dasar musik akusmatik, yakni penggunaan loudspeaker atau amplifikasi. Sedangkan pada peristiwa musik ketiga non live, tentunya hanya dapat diidentifikasi sesuai dengan kaidah atau prinsip dalam musik akusmatik.

Poin penting selanjutnya adalah, metode ini dikhususkan bagi para peneliti yang memiliki pemahaman dan pengalaman musikal. Alasan utamanya adalah terkait kepekaan menangkap dan memilah suara yang didengarkan (baca: mendengarkan), alasan selanjutnya adalah bahasa musikal yang hanya bisa dipahami oleh peneliti.

Tiap peneliti tentunya memiliki segudang pengalaman mendengar dan mendengarkan dalam kehidupan sehari-hari, maupun pada praktik penelitian. Peneliti yang awam tentang pengetahuan musikologis dalam kegiatan mendengarkan musik hanya akan sampai pada penilaian tentang baik dan buruk, enak dan tidak enak, suka tidak suka, dan sejenisnya. Maksudnya, penilaian yang dilakukan akan sangat bersifat subjektif daripada objektif. Sedangkan, peneliti dengan latar belakang pengetahuan musikologis memiliki kekhususan dalam hal pengalaman mendengar dan mendengarkan. Kekhususan tersebut bermuara pada penilaian yang lebih bersifat objektif pada peristiwa musikal tersebut. Di antaranya, bisa meliputi persoalan teoretis, teknik, sampai pada kepekaan terhadap kualitas teknis sound yang ditangkap oleh indra pendengaran peneliti.

Observasi yang dilakukan secara objektif pada musik yang didengarkan akan memberi data yang murni mengenai pemilihan subjek penelitian berfokus pada tiga kategori peristiwa dalam penelitian ini. Persoalan subjektifitas tidak menjadi persoalan dalam penelitian ini. Persoalan subjektifitas selanjutnya akan digali dan ditelusuri pada subjek pendengar. Data yang akan didapatkan melalui pendengar baru akan ditelusuri setelah observasi auditif ini dilakukan, dalam rangka mengonfirmasi data yang telah didapatkan sebelumnya. Selanjutnya, adalah dengan cara wawancara kepada masing-masing audiens pada setiap peristiwa, di mana hal tersebut juga tidak dibahas dalam tulisan ini. Tahapan berikutnya adalah tahap pemetaan secara teoretis yang kemudian disesuaikan dengan pendekatan serta pemilihan teoretis yang dipilih oleh peneliti berdasarkan kasus dan wacana apa yang hendak menjadi fokus peneliti. 


\section{Pembahasan}

\section{Mencari Ruang dalam Metode Observasi Auditif}

Dewasa ini, teknik pengumpulan data melalui observasi auditif bukanlah topik baru dalam dunia penelitian, meskipun masih tergolong minim dilakukan. Metode auditif muncul dari pencarian para antropolog yang berusaha mengeksplorasi indra pendengaran dibandingkan dengan indra visual. Berikut akan dipaparkan beberapa peneliti yang berkonsentrasi pada wilayah ini.

Buku dengan judul Writing Culture: The Poetics and Politics of Ethnography merupakan kumpulan tulisan antropologis yang cukup berpengaruh dan kontroversial dikalangan para antropolog selama tiga dekade ini (Clifford \& Marcus, 1986). Dalam buku ini, memunculkan pertanyaan yang cukup mengganggu para peneliti kala itu "but what of the ethnographic ear?" (Clifford \& Marcus, 1986, p. 12). Antropologi selalu berusaha mengurai makna yang kemudian dipahami sebagai tindakan membaca dan menafsirkan. Pertanyaan selanjutnya adalah, "lalu mengapa harus repot dengan telinga disaat semua bisa didapatkan dengan visualitas?". Pertanyaan-pertanyaan ini sebenarnya merupakan pemantik untuk kemudian memeriksa kembali potensi kemampuan indra lain yang bisa menyerap data dengan gaya dan cara yang berbeda.

Selanjutnya, dampak kritik visualisme yang dikemukakan oleh Walter Ong dan para sarjana oralitas lainnya mengenai antropologi interpretatif muncul. la mengklaim bahwa metafora dominan untuk etnografi telah bergeser dari mata yang mengamati menuju ucapan ekspresif (termasuk gerak tubuh). Antropologi lebih banyak menghasilkan "ucapan", tetapi agak sedikit penjelasan tentang praktik mendengarkan yang sebenarnya. Bukan berarti para antropolog telah memberi sedikit perhatian pada tubuh dan persepsi indra, tetapi hanya sedikit yang benar-benar mendekati indra lebih dari sekadar "teks" untuk dibaca (Clifford \& Marcus, 1986, p. 12). Melalui buku ini, kita dapat memperoleh pengertian yang lebih jelas dari keterbatasan dan masalah paradigma tekstual dan cara-cara di mana perhatian terhadap indra tidak hanya menghasilkan jenis data etnografi yang baru dan lebih kaya, tetapi juga memaksa kita untuk memikirkan kembali berbagai masalah teoretis dan metodologis.

Buku berjudul Hearing Cultures juga memfokuskan berbagai tulisan yang ada di dalamnya pada eksplorasi "pendengaran" dari segi metode dan teoretis (Erlmann, 2020). Dikatakan dalam buku ini bahwa gagasan pencarian untuk etnografi pendengaran membutuhkan lebih dari pemahaman metaforis etnografi yang membutuhkan lebih banyak dialog, telinga yang lebih peka, atau telinga ketiga (Erlmann, 2020). "Budaya mendengar" memberikan sebuah kemungkinan untuk mengonseptualisasikan cara-cara baru untuk mengetahui suatu budaya dan mendapatkan pemahaman yang mendalam tentang bagaimana anggota masyarakat mengenal satu sama lain. Bukan hanya dengan mengumpulkan kumpulan teks, penanda, dan simbol yang saling terkait, kita bisa merasakan hubungan dan ketegangan yang membentuk masyarakat. Cara-cara di mana orang berhubungan satu sama lain melalui indra pendengaran juga memberikan wawasan penting ke dalam berbagai masalah yang dihadapi masyarakat di seluruh dunia saat mereka bergulat dengan perubahan besar yang ditimbulkan oleh modernisasi, teknologi, dan globalisasi (ErImann, 2020). Pada sisi yang lain, buku ini membatasi penyelidikannya pada tataran suara ekstramusikal dalam esai yang ditujukan untuk musik dengan alasan bahwa, etnomusikologi dan musikologi merupakan dua disiplin ilmu yang menempatkan klaim superior terhadap persepsi suara dan pendengaran sebagai hak sulung mereka. 
Perhatian terhadap pentingnya domain auditif dalam bidang penelitian juga datang dari jaringan peneliti yang berpusat di Universitas Freie Jerman. Jaringan ini beranggotakan para peneliti yang berasal dari lintas negara, seperti Jerman, Inggris, Belanda, Swiss, dan Amerika Serikat. Pertanyaan utama yang memandu kelompok peneliti ini adalah peran mendengar atau mendengarkan dalam budaya pengetahuan modern. Modernitas telah lama dianggap sebagai zaman visual. Dalam hal ini, saya menangkap bahwa yang dilakukan oleh kelompok ini bukanlah dalam rangka menafikkan budaya visual, melainkan atas dasar keyakinan yang besar terhadap potensi pengetahuan auditif.

Berbagai studi yang dilakukan oleh kelompok ini berhasil menunjukkan dalam berbagai cara bahwa mendengar dan mendengarkan adalah faktor penting di zaman modern. Fokus penyelidikan mereka terutama pada berbagai bentuk budaya mendengar dari Abad 20 dan awal Abad 21. Hal ini bertujuan untuk mengeksplorasi status epistemik mendengar dan mendengarkan dalam modernitas (Admin, 2020). Kelompok ini kemudian merangkul konsep pengetahuan luas, yang mencakup pengetahuan implisit dan performatif, untuk mempertanyakan jenis pengetahuan pendengaran apa yang dapat direkonstruksi secara historis dan fitur mendengar dan pendengaran apa yang termasuk dalam proses produksi dan komunikasi pengetahuan? Kelompok ini kemudian memobilisasi pertanyaan-pertanyaan ini untuk menyelidiki bentuk-bentuk pengetahuan pendengaran apa yang dapat ditemukan dalam sains, musik, seni pertunjukan, sastra, filsafat, dan politik. Melalui pertanyaanpertanyaan ini, mereka mampu membuat konsep-konsep historis sentral, asumsi-asumsi, dan studi-studi yang baik untuk mempersoalkan hipotesis "hegemoni visual" dalam sejarah intelektual modernitas.

Selain persoalan metodologis pada teknik pengumpulan data, khususnya pada penelitian dalam bidang musik, bukan berarti tidak ada masalah dalam pelaksanaannya. Metode yang lazim dipakai dalam menganalisis suatu karya musik ialah menggunakan ilmu bentuk analisa (analisis musikologis) yang kemudian membedah notasi musik secara rinci satu demi satu notasi dianalisis berdasarkan sistem yang sudah menjadi konvensi dalam musikologi. Tak dapat dipungkiri bahwa dalam membedah suatu karya, analisis musikologis ini banyak meminjam terminologi dari bahasa sebagai jalan identifikasi.

Analisis lain yang sering dilakukan dalam membedah suatu karya musik adalah analisis makna semantik. Pada umumnya, analisis makna semantik merupakan langkah kedua setelah analisis bentuk musik selesai dilakukan. Salah satu kekurangan dari hasil interpretasi makna semantik mengacu pada hasil analisis yang cenderung bersifat arbiter, dimana hasil analisis musikologi yang terkesan mencocok-cocokkan bentuk-bentuk musik dengan persoalan ekstra musikal yang tingkat validitasnya masih bisa dipertanyakan kembali. Jika analisis tersebut dipakai dalam menganalisis kasus dalam tulisan ini, alih-alih menemukan jawaban atas pertanyaan, justru akan membuat pencarian semakin keruh. Hal ini terjadi dikarenakan analisis struktur musik dan analisis makna semantik tidak bisa lagi menjelaskan kompleksitas musik itu sendiri, apalagi jika dikaitkan dengan makna kehadiran yang menjadi pokok utama permasalahan pencarian metode dalam tulisan ini.

Beberapa pembahasan sebelumnya tidak hanya menyadarkan kita akan pentingnya salah satu indra yang kurang dipelajari, akan tetapi juga membuka ruang penelitian yang luas untuk ditelusuri. Terkhusus pada penelitian ini, teknik observasi auditif sebagai teknik pengumpulan data kualitatif menjadi titik fokusnya. 


\section{Tawaran Metode}

Teknik pengumpulan data dengan melakukan observasi auditif pada penelitian ini disebut sebagai teknik enharmonik. Observasi ini bersifat non-partisipan dan masih terbatas pada asumsi peneliti dalam melakukan observasi pada tiga kategori peristiwa berbeda yakni dalam dimensi live, semi-live, dan non-live.

Pada dasarnya teknik enharmonik masih sangat terkesan pribadi, dikarenakan kontekstualisasi kasus yang telah dijelaskan sebelumnya, juga latar belakang peneliti sebagai penulis di bidang musik. Terdapat beberapa kata kunci dalam metode ini, yakni mendengar dan mendengarkan, enharmonik, pengalaman dan pemahaman musikal, dan interpretasi teoretik yang masih belum komprehensif dibahas dalam penelitian ini. Selanjutnya akan dibahas secara beriringan dengan rencana aplikasinya. Observasi yang akan dibahas merupakan aplikasi pada observasi non-partisipan.

\section{Mendengar dan Mendengarkan}

Kutipan paragraf dalam buku Listening to Noise dan Silence mengindikasikan pentingnya untuk memahami terlebih dahulu perbedaaan terminologi mendengar dan mendengarkan, seperti yang terdapat dalam kutipan berikut:

Suara terus-menerus masuk ke telingaku, berputar-putar di sana, menyatakan minat mereka bahkan jika aku tidak mendengarkan. Ketika saya berjalan melalui jalan kota yang sibuk, saya mencoba mengabaikan dengung lalu lintas yang padat, keributan yang riuh, dan dengung suara orang-orang di sekitar saya. Namun, fakta bahwa saya tidak mendengarkan mereka secara sadar atau dengan sukarela tidak berarti bahwa suara-suara ini tidak membentuk kenyataan karena hal itu muncul dengan sendirinya kepada saya. Suara membuat kerumunan massa dan meresap, menjadi lebih padat dan lebih menakutkan, melanggar ruang fisik saya. Kaki mereka yang gemerincing bergema dari arsitektur yang keras dan berkilau. Menyerbu: muncul dari belakang dan membentang di depan saya dan di luar cakrawala visual saya. Mereka ada di mana-mana, semakin dekat dan dekat, menelan saya di hadapan fisik mereka (Voegelin, 2010, p. 11).

Secara lebih rinci, akan dijelaskan melalui tabel berikut:

Tabel 1. Perbandingan antara Mendengar (Hearing) dan Mendengarkan (Listening)

(Sumber: listeningear.in)

\begin{tabular}{ll}
\hline \multicolumn{1}{c}{ Mendengar (Hearing) } & \multicolumn{1}{c}{ Mendengarkan (Listening) } \\
\hline $\begin{array}{l}\text { Mendengar adalah tindakan merasakan suara } \\
\text { dan menerima gelombang atau getaran suara } \\
\text { melalui telinga }\end{array}$ & $\begin{array}{l}\text { Mendengarkan adalah tindakan } \\
\text { mendengar suara dan memahami apa } \\
\text { yang anda dengar }\end{array}$ \\
\hline $\begin{array}{l}\text { Medengar adalah salah dari lima indra dan itu } \\
\text { hanya terjadi sesaat - suka atau tidak - kecuali } \\
\text { jika seseorang memiliki gangguan pendengaran }\end{array}$ & $\begin{array}{l}\text { Mendengarkan Membutuhkan } \\
\text { konsentrasi agar otak anda memproses } \\
\text { makna dari kata-kata dan kalimat. }\end{array}$ \\
\hline Mendengar terjadi begitu saja & $\begin{array}{l}\text { Mendengarkan mengarah pada } \\
\text { pembelajaran. }\end{array}$ \\
\hline
\end{tabular}




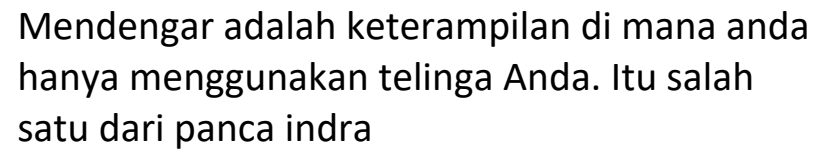

Pada tabel di atas, perbedaan antara mendengar dan mendengarkan pada dasarnya merupakan perbedaan yang bersifat biologis dan konstruktif. Fenomenologi Charles Sanders Peirce juga secara khusus memberikan wawasan unik tentang pengalaman mendengarkan. "Mendengarkan tidak dimulai dari kekosongan kesadaran, tetapi dari pendengaran", Dengan kata lain, mendengarkan bukanlah tindakan yang tidak dirangsang, tetapi disebabkan oleh tindakan, usaha, dan perlawanan yang menghasilkan kesadaran akan 'yang lain' yang bukan diri kita sendiri. Sedangkan 'berbicara' tidak memunculkan gagasan tentang perbedaan ini, 'mendengarkan' pada dasarnya mengasumsikan respons terhadap rangsangan eksternal, baik itu ekspresi, kata, atau gerakan (Bodie \& Crick, 2014, p. 118).

\section{Kesimpulan}

Penjabaran mengenai observasi auditif dengan teknik enharmonik ini adalah upaya mengejawantahkan kemungkinan metodis dalam penelitian seni. Seni yang dimaksud tidak hanya berfokus pada musik, tetapi membuka kemungkinan untuk cabang seni lainnya. Dengan kata lain, kekosongan metodis dalam ranah penelitian seni masih terbuka lebar untuk ditelusuri. Teknik pengumpulan data seperti yang telah dijelaskan memang merupakan teknik yang masih belum sampai dalam kategori ideal, tujuan tulisan ini lebih menitikberatkan sebagai pemantik akan pentingnya mengekplorasi potensi pengetahuan indra pendengaran dan kombinasi pengetahuan musikologis peneliti dalam persoalan metodologis. Namun demikian tulisan ini tentu saja memiliki banyak kekurangan yang perlu didiskusikan dan dieksplorasi lebih lanjut

\section{Referensi}

Admin. (2020). WhatsApp messages no longer need to be typed; but dictation is simply a smarter keyboard at work. Hear Knowledge as Trantition.

Andaryani, E. T. (2019). Pengaruh Musik Sebagai Moodboster Mahasiswa. Musikolastika: Jurnal Pertunjukan Dan Pendidikan Musik, 1(2), 109-115.

Apel, W. (2003). The Harvard dictionary of music. Harvard University Press.

Auslander, P. (2008). Liveness: Performance in a mediatized culture. Routledge.

Bodie, G. D., \& Crick, N. (2014). Listening, hearing, sensing: Three modes of being and the phenomenology of Charles Sanders Peirce. Communication Theory, 24(2), 105-123. 
Clifford, J., \& Marcus, G. E. (1986). Writing culture: the poetics and politics of ethnography: a School of American Research advanced seminar. Univ of California Press.

Erlmann, V. (2020). Hearing cultures: Essays on sound, listening and modernity. Routledge.

Eurich, B., Klenzner, T., \& Oehler, M. (2019). Impact of room acoustic parameters on speech and music perception among participants with cochlear implants. Hearing Research, 377, 122-132. https://doi.org/10.1016/j.heares.2019.03.012

Hanik, N. R., Harsono, S., \& Nugroho, A. A. (2018). Penerapan Pendekatan Contextual Teaching and Learning Dengan Metode Observasi Untuk Meningkatkan Hasil Belajar Pada Matakuliah Ekologi Dasar. Jurnal Pendidikan Matematika Dan IPA, 9(2), 127-138.

Hasanah, H. (2017). Teknik-teknik observasi (sebuah alternatif metode pengumpulan data kualitatif ilmu-ilmu sosial). At-Taqaddum, 8(1), 21-46.

Koelsch, S., Vuust, P., \& Friston, K. (2019). Predictive Processes and the Peculiar Case of Music. Trends in Cognitive Sciences, 23(1), 63-77. https://doi.org/10.1016/j.tics.2018.10.006

Makhin, S. A., Makaricheva, A. A., Lutsuk, N. V, \& Pavlenko, V. B. (2015). Study of the reactivity of the $\mu$ rhythm during observation, auditory perception, and movement imitation: Correlation with empathic ability. Human Physiology, 41(6), 593-598.

Phelan, P. (1993). Unmarked: The politics of performanceRoutledge. New York.

Phillips-Silver, J., \& Trainor, L. J. (2007). Hearing what the body feels: Auditory encoding of rhythmic movement. Cognition, 105(3), 533-546.

Rahardjo, M. (2011). Metode pengumpulan data penelitian kualitatif.

Sato, A. (2008). Action observation modulates auditory perception of the consequence of others' actions. Consciousness and Cognition, 17(4), 1219-1227.

Septiyan, D. D. (2019). Pengaruh Habitus Dari Selera Musik Terhadap Konsep Diri Penikmatnya. Musikolastika: Jurnal Pertunjukan Dan Pendidikan Musik, 1(2), 101-108.

Shea, C. H., Wulf, G., Park, J.-H., \& Gaunt, B. (2001). Effects of an auditory model on the learning of relative and absolute timing. Journal of Motor Behavior, 33(2), 127-138.

Voegelin, S. (2010). Listening to noise and silence: Towards a philosophy of sound art. Bloomsbury Publishing USA.

Young, W. R., Rodger, M. W. M., \& Craig, C. M. (2014). Auditory observation of stepping actions can cue both spatial and temporal components of gait in Parkinson's disease patients. Neuropsychologia, 57, 140-153. 